\title{
Protective mechanisms against protein damage in hyperhomocysteinemia: Systemic and renal detoxification of homocysteine-thiolactone
}

\author{
Hieronim Jakubowski ${ }^{1-3 *}$ \\ ${ }^{1}$ Department of Microbiology, Biochemistry and Molecular Genetics, Rutgers-New Jersey Medical School, International Center for Public Health, Newark, USA \\ ${ }^{2}$ Department of Biochemistry and Biotechnology, University of Life Sciences, Poland \\ ${ }^{3}$ Institute of Bioorganic Chemistry, Poland
}

\begin{abstract}
Homocysteine (Hcy) and its metabolite Hcy-thiolactone (HTL) are implicated in cardiovascular disease (CVD). Recent studies show that HTL is a predictor of acute myocardial infarction in CVD patients, independent of established risk factors and plasma total Hcy. HTL is formed in all cell types as a result of error-editing reactions in protein biosynthesis. Its ability to $\mathrm{N}$-homocysteinylate protein lysine residues and cause protein damage has been mechanistically linked to the pathology of CVD induced by hyperhomocysteinemia. Specific HTL-detoxifying mechanisms have been identified that can potentially be exploited for modulation of HTL levels and the risk of CVD.
\end{abstract}

\section{Introduction}

Traditional risk factors account only for half of cardiovascular disease (CVD) cases. Thus, there is a need to study other CVD risk factors and elucidate their mechanism of action. Mildly elevated plasma total homocysteine (tHcy) is an emerging risk factor [1] that is associated with increased risk of CVD and is a strong predictor of mortality in cardiovascular patients [2]. Folic acid and B-vitamin supplementation lowers plasma tHcy and has been studied for primary and secondary prevention of CVD outcomes in large-scale randomized controlled trials (RCTs). In individual RCTs, lowering plasma tHcy by folic acid and B-vitamin supplementation protects against stroke $[3,4]$, but not myocardial infarction $[5,6]$. However, meta-analyses of 8 RCTs involving 37,485 individuals [7] completed by the end of 2009 and 24 RCTs involving 57,952 individuals [8] completed by April 2013 show that tHcy-lowering by B-vitamin supplementation has no effect on CVD outcomes.

A possible reason for these dissonant results is that tHcy is a composite marker comprising of different Hcy species, but not encompassing a chemically reactive and toxic Hcy metabolite-Hcythiolactone (HTL)-which has been independently implicated in CVD [9]. Indeed, recent studies show that HTL is a predictor of acute myocardial infarction in CVD patients, independent of established risk factors and plasma total Hcy [10]. Moreover, HTL levels are not reduced by folic acid/vitamin $B_{12}$ treatments that lower Hcy [10]. HTL, produced in an Hcy-editing reaction during protein biosynthesis $[11,12]$, can promote CVD due to its ability to form isopeptide bonds with protein lysine residues, which generates toxic $\mathrm{N}$-Hcy-proteins with pro-inflammatory, pro-thrombotic, pro-atherogenic, and proamyloidal properties [9].

Because HTL accumulation compromises biological integrity, humans and animals have evolved mechanisms to eliminate or detoxify HTL. One such mechanism involves enzymatic hydrolysis by HTL hydrolases (HTLases): serum HTLase/paraoxonase 1 (PON1) [13], cytoplasmic HTLase/bleomycin hydrolase (BLMH) [14], and mitochondrial HTLase/bisphenol hydrolase-like (BPHL) [15-17].

\section{Paraoxonase 1}

PON1 is a calcium-dependent enzyme synthesized in the liver and circulating in the blood attached to high-density lipoprotein HDL; it is the first well-characterized HTLase $[13,18]$. Pon1, named for its ability to detoxify the organophosphate paraoxon, is implicated in CVD and Alzheimer's disease (AD). For example, low serum Pon1 activity is a risk factor for dementia [19] and $\mathrm{AD}[20,21]$, while Hcy is a negative determinant of Pon1 activity [22,23] and a risk factor for AD [24]. Emerging evidence strongly suggests that PON1 activity is linked to CVD risk. For instance, PON1 protects against (high-fat diet-induced) atherosclerosis in humans [25,26] and mice [27]. The cardio-protective function of PON1 has been mechanistically linked with its ability to modulate indices of oxidative stress [26,27] and to detoxify HTL $[13,28,29]$. HDL and purified PON1 have the ability to hydrolyze HTL [13] and to protect against the accumulation of $\mathrm{N}$-Hcy-protein in vitro $[30,31]$ and in vivo in humans [28].

Substrate specificity studies of purified human serum PON1 show that $L$-HTL is a preferred physiological substrate [13] (Table

Correspondence to: Hieronim Jakubowski, Department of Microbiology, Biochemistry and Molecular Genetics, Rutgers-New Jersey Medical School, International Center for Public Health, Newark, NJ 07103, USA, Tel: 973-9728733, Fax: 973-972-8981, E-mail: jakubows@rutgers.edu

Keywords: atherosclerosis, homocysteine thiolactone, PON1, BLMH, BPHL, renal function

Received: June 01, 2016; Accepted: June 25, 2016; Published: June 28, 2016 
1). Non-physiological substrates $D$-HTL and $\gamma$-thiobutyrolactone are hydrolyzed at a rate 4 -fold slower and 5.5 -fold faster, respectively, than $L$-HTL by the enzyme. Other non-physiological substrates phenyl acetate and paraoxon (hydrolyzed 2,800- and 3.3-times faster that $\mathrm{r} L$ HTL) are non-competitive inhibitors of the HTLase activity suggesting that HTL, phenyl acetate, and paraoxon are hydrolyzed at different sites of the enzyme [13]. This suggestion is supported by structure/ function studies showing that specific active sites mutations have different effects on arylesterase, paraoxonase, and lactonase activities of the PON1 protein $[32,33]$. Other inhibitors of the HTL activity, such as isoleucine and penicillamine are also non-competitive, suggesting the presence of a distinct amino acid-binding effector site on PON1 [13]. HTLase and paraoxonase activities are strongly correlated in various populations $[22,28,31]$, indicating that the non-physiological paraoxonase activity is a good surrogate for the physiological HTLase activity of the PON1 protein.

Human PON1 has two major genetic polymorphisms: PON1-M55L and PON1-R192Q, which affect PON1 function [34,35], including its HTLase activity $[22,31]$. For example, high HTLase activity is associated with PON1-L55 and PON1-R192 alleles, whereas low HTLase activity is associated with PON1-M55 and PON1-Q192 alleles [22,31]. Purified serum PON1-R192 allozyme has 2.5-fold higher HTLase activity than the PON1-Q192 allozyme [36], which explains the association of high activity with PON1-R192 allele. However, several studies have found that PON1 phenotype (HTLase or paraoxonase activity) is a predictor of cardiovascular disease but the PON1-R192Q or PON1-M55L genotypes are not [22,34,35,37-39]. For example, HTLase activity is found to be significantly lower in a group of 128 CVD patients with angiographically confirmed atherosclerotic lesions, compared to a control group of 142 individuals who have no lesions [39]. A negative correlation is found between the severity of atherosclerotic lesions and HTLase activity in patients. Further, the physiological HTLase activity is a more significant predictor of CVD than a non-physiological paraoxonase activity [39].

In humans, the HTLase activity (but not arylesterase or $\gamma$-butyrothiolactonase) of PON1 is a determinant of plasma $\mathrm{N}$-Hcyprotein levels and protects proteins against $\mathrm{N}$-homocysteinylation in vivo, a novel mechanism likely to contribute to atheroprotective roles of HDL $[18,28]$. HTLase activity of PON1 is negatively correlated with tHcy [22] and predicts CVD (38). Pon $1^{-1-}$ mice are impaired in their ability to hydrolyze HTL and as a result heve elevated levels of plasma $\mathrm{N}$-Hcy-protein and excrete more HTL in the urine compared with their Pon $1^{+/+}$littermates [29]. Pon $1^{-1-}$ mice are also more sensitive than their wild type littermates to neurotoxicity of HTL. Taken together, these studies provide the first direct evidence that a specific Hcy metabolite, HTL, rather than Hcy itself is neurotoxic in vivo [29], and suggest that other functional properties of HDL beyond its ability to promote reverse cholesterol transport contribute to its atheroprotective function.

\section{Bleomycin hydrolase}

Bleomycin hydrolase (Blmh), is a thiol-dependent cytoplasmic aminopeptidase expressed in various organs, including the liver [40]. Blmh is studied in the context of Hcy toxicity [14,41], cancer therapy [42,43], AD [44-47], Huntington disease [48], keratinization disorders [49], and protein breakdown $[48,50]$. The human genetic polymorphism $B L M H-I l e 443 \mathrm{Val}$ is associated with an increased risk for AD [45]. In mice, deletion of the Blmh gene results in several phenotypes, such as neonatal mortality, tail dermatitis [51], brain pathology [52], and impairs the presentation of some antigens [53].

In addition to an aminopeptidase activity, Blmh has a hydrolase activity towards HTL [14,54] (Table 1). Substrate specificity studies of purified human Blmh show that the enzyme exhibits absolute stereospecicity for $L$-HTL, the preferred natural substrate [14]. Methyl esters of $L$-Cys and $L$-Met, but not of other $L$-amino acids, are also hydrolyzed. However, D-HTL, D-Met methyl ester, $\gamma$-thiobutyrolactone, $L$-homoserine lactone are not hydrolyzed by Blmh [14].

HTLase activity of Blmh is significantly reduced in brains from Alzheimer's disease patients compared with unaffected brains [41]. This finding suggests that diminished functional Blmh activity could contribute to the pathology of the disease.

Catabolism of HTL is impaired in $B l m h^{-/}$mice. For example, Blmh I- mice have elevated brain and kidney HTL, and plasma $\mathrm{N}$-Hcy-protein levels compared with wild type $B l m h^{+/+}$littermates [54]. Blmh $h^{-/}$mice are significantly more sensitive to HTL toxicity than their wild type littermates [54].

\section{Biphenyl hydrolase-like protein}

Biphenyl hydrolase-like protein (BPHL), also called valacyclovir hydrolase, is a mitochondrial protein highly expressed in human liver and kidney $[55,56]$. BPHL hydrolyzes and activates the antiviral prodrug esters valacyclovir and valganciclovir, used in the management of herpes simplex, herpes zoster (shingles) and herpes B [57]. First cloned from breast carcinoma cells, BPHL, a member of the alpha/beta hydrolase fold family, is a serine hydrolase distantly related to other members of the serine hydrolase family [55,56]. In mice, deletion of the $B p h l$ gene results decreased circulating creatinine levels in males, suggesting a kidney function defect (http://www.informatics.jax.org/ allele/allgenoviews/MGI:5548556).

First reports showing that human BPHL has an HTLase activity were published in 2010-2011 [15,16] and confirmed in 2014 [17]. Although BPHL, BLMH, and PON1, hydrolyze HTL, they differ in catalytic efficiencies and exhibit distinct specificities towards nonphysiological substrates (Table 1). Catalytic efficiency of BPHL for HTL hydrolysis is higher than that of BLMH or PON1, suggesting a significant HTL- detoxifying role for BPHL in vivo, which remains to

Table 1. Substrate specificities of human HTLases.

\begin{tabular}{|l|c|c|c|}
\hline Substrate & $\begin{array}{c}\text { PON1 } \\
\text { activity, } \%\end{array}$ & BLMH activity, \% & $\begin{array}{c}\text { BPHL } \\
\text { activity, } \%\end{array}$ \\
\hline $\begin{array}{l}L \text {-Hcy-thiolactone } \\
\left(\mathrm{k}_{\text {cat }} / \mathrm{K}_{\mathrm{m}}\right)\end{array}$ & $\begin{array}{c}100 \\
\left(10 \mathrm{M}^{-1} \mathrm{~s}^{-1}\right)\end{array}$ & $\begin{array}{c}100 \\
\left(10^{3} \mathrm{M}^{-1} \mathrm{~s}^{-1}\right)\end{array}$ & $\begin{array}{c}100 \\
\left(7.7 \times 10^{4} \mathrm{M}^{-1} \mathrm{~s}^{-1}\right)\end{array}$ \\
\hline$D$-Hcy-thiolactone & 24 & $<1$ & $\mathrm{ND}$ \\
\hline$\gamma$-Thiobutyrolactone & 545 & $<1$ & $<0.001$ \\
\hline$N$-Acetyl- $D, L$-HTL & $<1$ & $<1$ & $<0.001$ \\
\hline$L$-Hse-lactone & ++++ & - & +++ \\
\hline$L$-Met methyl ester & $<1$ & ++ & 30 \\
\hline$L$-Cys methyl ester & $<1$ & ++ & ++ \\
\hline$L$-Lys methyl ester & $\mathrm{ND}$ & - & 16 \\
\hline$L$-Phe ethyl ester & 0 & $\mathrm{ND}$ & $\mathrm{ND}$ \\
\hline$N \varepsilon$-Hcy-aminocaproate & $\mathrm{ND}$ & ++++ & $\mathrm{ND}$ \\
\hline Val $(N \varepsilon$-Hcy-Lys $)$ & $\mathrm{ND}$ & ++++ & $\mathrm{ND}$ \\
\hline HcyLeuAla & $\mathrm{ND}$ & ++++ & $\mathrm{ND}$ \\
\hline Bleomycin & $\mathrm{ND}$ & 500 & $\mathrm{ND}$ \\
\hline Paraoxon & 330 & - & $<0.001$ \\
\hline Phenyl acetate & 280,000 & - & 22 \\
\hline Valacyclovir & - & $\mathrm{ND}$ & + \\
\hline
\end{tabular}


be examined in future studies.

\section{HTL clearance by renal excretion}

In humans and mice endogenous HTL is also eliminated by urinary excretion [58,59]. HTL concentrations in urine vary from $11 \mathrm{nM}$ to 485 $\mathrm{nM}$ and are 100-forld higher than in plasma. Urinary HTL accounts for $2.5 \%-28 \%$ of urinary tHcy. Relative renal clearance of HTL is $0.2-7.0$ of creatinine clearance, while clearance of tHcy is only about $0.001-$ 0.003 [58]. Efficient urinary elimination of HTL is typical for the waste or toxic products of normal human metabolism.

Calculations based on a normal glomerular filtration rate of $180 \mathrm{~L} /$ day and a free plasma Hcy concentrations of $3 \mu \mathrm{M}$ indicate that $99 \%$ of filtered tHcy is reabsorbed [60] in humans. A similar calculation for HTL $(0.12-2.4 \mathrm{nM}$ in plasma and $286-415 \mathrm{nmol} /$ day eliminated in urine) indicates that only $0.4-3.8 \%$ is reabsorbed and $>95 \%$ of filtered HTL was excreted [58].

In mice fed with a normal chow diet, urinary HTL is $140 \mathrm{nM}$ [59], similar to urinary HTL value in humans [58]. However, in mice with dietary (high-Met) or genetic $\left(\mathrm{Cbs}^{-/}\right)$hyperhomocysteinemia urinary HTL increases 25-fold [59] or $>50$-fold [61]. The distributions of HTL between plasma and urine in mice fed a normal diet and humans are similar: HTL accumulates to much higher levels in urine than in plasma (the ratio urinary/plasma HTL is 37 in mice [59] and 100 in humans [58]). This shows that urinary clearances of HTL in mice and humans are similar, and that in mice, similar to humans [58], $>95 \%$ of the filtered HTL is excreted with urine. Furthermore, significantly higher urinary/plasma HTL ratios are found in mice fed with a high-Met diet than in the animals fed a normal diet, which suggests that efficiency of urinary HTL clearance increases in hyperhomocysteinemia.

Renal excretion removes a large fraction of HTL [58] that would otherwise cause protein damage by $\mathrm{N}$-homocysteinylation. Thus, urinary excretion is an important route of HTL elimination and intact renal function is essential for HTL detoxification in humans and mice.

\section{Implications}

Given the role of PON1, BLMH, and BPHL in the detoxification of Hcy-thiolactone, available evidence supports the possibility that elevated HTLase activity might protect against CVD in the general population. Dietary, pharmacological, or genetic interventions to increase or preserve HTLase activity might provide basis for CVD prevention or treatment. Such strategies are feasible with PON1 as shown by studies in which dietary consumption of red wine or its flavonoids quercetin and catechinwas shown to preserve serum PON1 activity in $A p o E^{-1-}$ mice [62]. Pomegranate juice, which is rich in flavonoids, causes significant elevations in PON1 activity in humans and reduces the size of atherosclerotic lesions in $A p o E^{-/}$mice [63]. Further, PON1 overexpression in mice inhibits atherosclerosis development [64]. Identification of determinants of PON1, BLMH, and BPHL activity and subsequent human intervention studies are needed to examine these potential therapeutic implications.

\section{Acknowledgements}

Studies from the Author's lab were supported in part by grants 2012/07/B/NZ7/01178, 2013/09/B/NZ5/02794, 2013/11/B/NZ1/00091 from the National Science Center and 12GRNT9420014 from the American Heart Association.

\section{References}

1. Shishehbor MH, Oliveira LP, Lauer MS, Sprecher DL, Wolski K, et al. (2008) Emerging cardiovascular risk factors that account for a significant portion of attributable mortality risk in chronic kidney disease. Am J Cardiol 101: 1741-1746. [Crossref]

2. Maron BA, Loscalzo J (2009) The treatment of hyperhomocysteinemia. Annu Rev Med 60: 39-54.[Crossref]

3. Saposnik G, Ray JG, Sheridan P, McQueen M, Lonn E; Heart Outcomes Prevention Evaluation 2 Investigators (2009) Homocysteine-lowering therapy and stroke risk, severity, and disability: additional findings from the HOPE 2 trial. Stroke 40: 13651372.[Crossref]

4. Spence JD, Bang H, Chambless LE, Stampfer MJ (2005) Vitamin Intervention For Stroke Prevention trial: an efficacy analysis. Stroke 36: 2404-2409.[Crossref]

5. Lonn E, Yusuf S, Arnold MJ, Sheridan P, Pogue J, et al. (2006) Homocysteine lowering with folic acid and B vitamins in vascular disease. N Engl J Med 354: 1567-1577. [Crossref]

6. Ebbing M, Bleie Ø, Ueland PM, Nordrehaug JE, Nilsen DW, et al. (2008) Mortality and cardiovascular events in patients treated with homocysteine-lowering B vitamins after coronary angiography: a randomized controlled trial. JAMA 300: 795-804. [Crossref]

7. Clarke R, Halsey J, Lewington S, Lonn E, Armitage J, et al. (2010) Effects of lowering homocysteine levels with B vitamins on cardiovascular disease, cancer, and causespecific mortality: Meta-analysis of 8 randomized trials involving 37485 individuals. Arch Intern Med 170: 1622-1631. [Crossref]

8. Zhang C, Wang ZY, Qin YY, Yu FF, Zhou YH (2014) Association between B vitamins supplementation and risk of cardiovascular outcomes: a cumulative meta-analysis of randomized controlled trials. PloS one 9: e107060. [Crossref]

9. Jakubowski H (2013) Homocysteine in Protein Structure/Function and Human Disease - Chemical Biology of Homocysteine-containing Proteins, Springer, Wien.

10. Jakubowski H, Borowczyk K, Glowacki R, Nygård O (2015) Urinary HomocysteineThiolactone Predicts Acute Myocardial Infarction in a Randomized Controlled Homocysteine-lowering B-vitamin Trial. Circulation 132: A19250.

11. Jakubowski H (2011) Quality control in tRNA charging -- editing of homocysteine. Acta Biochim Pol 58: 149-163.[Crossref]

12. Jakubowski H (2012) Quality control in tRNA charging. Wiley Interdiscip Rev RNA 3: 295-310.[Crossref]

13. Jakubowski H (2000) Calcium-dependent human serum homocysteinethiolactone hydrolase. A protective mechanism against protein $\mathrm{N}$-homocysteinylation. J Biol Chem 275: 3957-3962. [Crossref]

14. Zimny J, Sikora M, Guranowski A, Jakubowski H (2006) Protective mechanisms against homocysteine toxicity: the role of bleomycin hydrolase. $J$ Biol Chem 281: 22485-22492.[Crossref]

15. Zimny J, Bretes E, Guranowski A (2010) Novel mammalian homocysteinethiolactone hydrolase: Purification and characterization. Acta Biochemica Polonica 57: 134.

16. Zimny J, Bretes E, Grygiel D, Guranowski A (2011) Human mitochondrial homocysteinethiolactone hydrolase; overexpression and purification. Actabiochimica Polonica 58: 57.

17. Marsillach J, Suzuki SM, Richter RJ, McDonald MG, Rademacher PM, et al.(2014) Human valacyclovir hydrolase/biphenyl hydrolase-like protein is a highly efficient homocysteinethiolactonase. PloS one 9: e110054. [Crossref]

18. Perla-Kajan J, Jakubowski H (2012) Paraoxonase 1 and homocysteine metabolism. Amino Acids 43: 1405-1417.[Crossref]

19. Dantoine TF, Debord J, Merle L, Lacroix-Ramiandrisoa H, Bourzeix L, et al. (2002) Paraoxonase 1 activity: a new vascular marker of dementia? Ann N Y Acad Sci 977: 96-101.[Crossref]

20. Paragh G, Balla P, Katona E, Seres I, Egerházi A, et al. (2002) Serum paraoxonase activity changes in patients with Alzheimer's disease and vascular dementia. Eur Arch Psychiatry Clin Neurosci 252: 63-67. [Crossref]

21. Erlich PM, Lunetta KL, Cupples LA, Abraham CR, Green RC, et al. (2010) Serum paraoxonase activity is associated with variants in the PON gene cluster and risk of Alzheimer disease. Neurobiol Aging 33: 1015.e7-23. [Crossref]

22. Lacinski M, Skorupski W, Cieslinski A, Sokolowska J, Trzeciak WH, et al. (2004) Determinants of homocysteine-thiolactonase activity of the paraoxonase-1 (PON1) protein in humans. Cell Mol Biol (Noisy-le-grand) 50: 885-893.[Crossref]

23. Wehr H, Bednarska-Makaruk M, Graban A, Lipczynska-Lojkowska W, Rodo M, et al (2009) Paraoxonase activity and dementia. J Neurol Sci 283: 107-108.[Crossref] 
24. Smith AD, Smith SM, de Jager CA, Whitbread P, Johnston C, et al. (2010) Homocysteine-lowering by B vitamins slows the rate of accelerated brain atrophy in mild cognitive impairment: a randomized controlled trial. PLoS One 5: e12244. [Crossref]

25. Kunutsor SK, Bakker SJ, James RW, Dullaart RP (2016) Serum paraoxonase-1 activity and risk of incident cardiovascular disease: The PREVEND study and meta-analysis of prospective population studies. Atherosclerosis 245: 143-154. [Crossref]

26. Bhattacharyya T, Nicholls SJ, Topol EJ, Zhang R, Yang X, et al. (2008) Relationship of paraoxonase 1 (PON1) gene polymorphisms and functional activity with systemic oxidative stress and cardiovascular risk. JAMA 299: 1265-1276. [Crossref]

27. Shih DM, Gu L, Xia YR, Navab M, Li WF, et al. (1998) Mice lacking serum paraoxonase are susceptible to organophosphate toxicity and atherosclerosis. Nature 394: 284-287.[Crossref]

28. Perla-Kajan J, Jakubowski H (2010) Paraoxonase 1 protects against protein N-homocysteinylation in humans. FASEB $J$ 24: 931-936. [Crossref]

29. Borowczyk K, Shih DM, Jakubowski H (2012) Metabolism and neurotoxicity of homocysteinethiolactone in mice: evidence for a protective role of paraoxonase $1 . J$ Alzheimers Dis 30: 225-231.[Crossref]

30. Jakubowski H, Zhang L, Bardeguez A, Aviv A (2000) Homocysteinethiolactone and protein homocysteinylation in human endothelial cells: implications for atherosclerosis. Circ Res 87: 45-51. [Crossref]

31. Jakubowski H, Ambrosius WT, Pratt JH (2001) Genetic determinants of homocysteinethiolactonase activity in humans: implications for atherosclerosis. FEBS Lett 491: 35-39. [Crossref]

32. Harel M, Aharoni A, Gaidukov L, Brumshtein B, Khersonsky O, et al. (2004) Structure and evolution of the serum paraoxonase family of detoxifying and anti-atherosclerotic enzymes. Nat Struct Mole Biol 11: 412-419. [Crossref]

33. Ben-David M, Elias M, Filippi JJ, Duñach E, Silman I, et al. (2012) Catalytic versatility and backups in enzyme active sites: the case of serum paraoxonase 1. J Mol Biol 418: 181-196.[Crossref]

34. Jarvik GP, Hatsukami TS, Carlson C, Richter RJ, Jampsa R, et al. (2003) Paraoxonase activity, but not haplotype utilizing the linkage disequilibrium structure, predicts vascular disease. Arterioscler Thromb Vasc Biol 23: 1465-1471. [Crossref]

35. Jarvik GP, Rozek LS, Brophy VH, Hatsukami TS, Richter RJ, et al. (2000) Paraoxonase (PON1) phenotype is a better predictor of vascular disease than is PON1(192) or PON1(55) genotype. Arterioscler Thromb Vasc Biol 20: 2441-2447.[Crossref]

36. Bayrak A, Bayrak T, Demirpençe E, Kılınç K (2011) Differential hydrolysis of homocysteinethiolactone by purified human serum (192)Q and (192)R PON1 isoenzymes. J Chromatogr B Analyt Technol Biomed Life Sci 879: 49-55. [Crossref]

37. Mackness B, Davies GK, Turkie W, Lee E, Roberts DH, et al. (2001) Paraoxonase status in coronary heart disease: are activity and concentration more important than genotype? Arterioscler Thromb Vasc Biol 21: 1451-1457. [Crossref]

38. Domagala TB, Lacinski M, Trzeciak WH, Mackness B, Mackness MI, et al. (2006) The correlation of homocysteine-thiolactonase activity of the paraoxonase (PON1) protein with coronary heart disease status. Cell Mol Biol (Noisy-le-grand) 52: 4-10.[Crossref]

39. Bayrak A, Bayrak T, Tokgözoglu SL, Volkan-Salanci B, Deniz A, et al. (2012) Serum PON-1 activity but not Q192R polymorphism is related to the extent of atherosclerosis. J Atheroscler Thromb 19: 376-384.[Crossref]

40. Kamata Y, Itoh Y, Kajiya A, Karasawa S, Sakatani C, et al. (2007) Quantification of neutral cysteine protease bleomycin hydrolase and its localization in rat tissues. $J$ Biochem 141: 69-76.[Crossref]

41. Suszynska J, Tisonczyk J, Lee HG, Smith MA, Jakubowski H (2010) Reduced homocysteine-thiolactonase activity in Alzheimer's disease. J Alzheimers Dis 19: 11771183.[Crossref]

42. Brömme D, Rossi AB, Smeekens SP, Anderson DC, Payan DG (1996) Human bleomycin hydrolase: molecular cloning, sequencing, functional expression, and enzymatic characterization. Biochemistry 35: 6706-6714. [Crossref]

43. Okamura Y, Nomoto S, Hayashi M, Hishida M, Nishikawa Y, et al. (2011) Identification of the bleomycin hydrolase gene as a methylated tumor suppressor gene in hepatocellular carcinoma using a novel triple-combination array method. Cancer Lett 312: 150-157. [Crossref]

44. Kajiya A, Kaji H, Isobe T, Takeda A (2006) Processing of amyloid beta-peptides by neutral cysteine protease bleomycin hydrolase. Protein Pept Lett 13: 119-123.[Crossref]

45. Papassotiropoulos A, Bagli M, Jessen F, Frahnert C, Rao ML, et al. (2000) Confirmation of the association between bleomycin hydrolase genotype and Alzheimer's disease. Mol Psychiatry 5: 213-215. [Crossref]

46. Lefterov IM, Koldamova RP, Lefterova MI, Schwartz DR, Lazo JS (2001) Cysteine 73 in bleomycin hydrolase is critical for amyloid precursor protein processing. Biochem Biophys Res Commun 283: 994-999. [Crossref]

47. Kajiya A, Kaji H, Isobe T, Takeda A (2006) Processing of amyloid beta-peptides by neutral cysteine protease bleomycin hydrolase. Protein Pept Lett 13: 119-123.[Crossref]

48. Ratovitski T, Chighladze E, Waldron E, Hirschhorn RR, Ross CA (2011) Cysteine proteases bleomycin hydrolase and cathepsin $\mathrm{Z}$ mediate $\mathrm{N}$-terminal proteolysis and toxicity of mutant huntingtin. $J$ Biol Chem 286: 12578-12589. [Crossref]

49. Kamata Y, Maejima H, Watarai A, Saito N, Katsuoka K, et al. (2012) Expression of bleomycin hydrolase in keratinization disorders. Arch Dermatol Res 304: 31-38. [Crossref]

50. Kamata Y, Taniguchi A, Yamamoto M, Nomura J, Ishihara K,et al. (2009) Neutral cysteine protease bleomycin hydrolase is essential for the breakdown of deiminatedfilaggrin into amino acids. J Biol Chem 284: 12829-12836. [Crossref]

51. Schwartz DR, Homanics GE, Hoyt DG, Klein E, Abernethy J, et al. (1999) The neutral cysteine protease bleomycin hydrolase is essential for epidermal integrity and bleomycin resistance. Proc Natl Acad Sci U S A 96: 4680-4685. [Crossref]

52. Montoya SE, Thiels E, Card JP, Lazo JS (2007) Astrogliosis and behavioral changes in mice lacking the neutral cysteine protease bleomycin hydrolase. Neuroscience 146: 890-900.[Crossref]

53. Towne CF, York IA, Watkin LB, Lazo JS, Rock KL (2007) Analysis of the role of bleomycin hydrolase in antigen presentation and the generation of CD8 $\mathrm{T}$ cell responses. J Immunol 178: 6923-6930.[Crossref]

54. Borowczyk K, TisoÅ,,czyk J, Jakubowski H (2012) Metabolism and neurotoxicity of homocysteinethiolactone in mice: protective role of bleomycin hydrolase. Amino Acids 43: 1339-1348.[Crossref]

55. Puente XS, Lopez-Otin C (1995) Cloning and expression analysis of a novel human serine hydrolase with sequence similarity to prokaryotic enzymes involved in the degradation of aromatic compounds. J Biol Chem 270: 12926-12932. [Crossref]

56. Puente XS, Pendás AM, López-otín C (1998) Structural characterization and chromosomal localization of the gene encoding human biphenyl hydrolase-related protein (BPHL). Genomics 51: 459-462.[Crossref]

57. Jung YJ, Doh MJ, Kim IH, Kong HS, Lee JS, et al. (2003) Prednisolone 21-sulfate sodium: a colon-specific pro-drug of prednisolone. J Pharm Pharmaco 155: 1075-1082. [Crossref]

58. Chwatko G, Jakubowski H (2005) Urinary excretion of homocysteine-thiolactone in humans. ClinChem51: 408-415.[Crossref]

59. Chwatko G, Boers GH, Strauss KA, Shih DM, Jakubowski H (2007) Mutations in methylenetetrahydrofolatereductase or cystathionine beta-synthase gene, or a highmethionine diet, increase homocysteinethiolactone levels in humans and mice. FASEB J21: 1707-1713. [Crossref]

60. vanGuldener C, Stehouwer CD (2003) Homocysteine metabolism in renal disease. Clin Chem Lab Med 41: 1412-1417.[Crossref]

61. Jakubowski H (2016) Quantification of urinary S- and N-homocysteinylated protein and homocysteine-thiolactone in mice. Anal Biochem.[Crossref]

62. Hayek T, Fuhrman B, Vaya J, Rosenblat M, Belinky P, et al. (1997) Reduced progression of atherosclerosis in apolipoprotein E-deficient mice following consumption of red wine, or its polyphenols quercetin or catechin, is associated with reduced susceptibility of LDL to oxidation and aggregation. Arterioscler Thromb Vasc Biol 17: 2744-2752. [Crossref]

63. Aviram M, Dornfeld L, Rosenblat M, Volkova N, Kaplan M, et al. (2000) Pomegranate juice consumption reduces oxidative stress, atherogenic modifications to LDL, and platelet aggregation: studies in humans and in atherosclerotic apolipoprotein E-deficient mice. Am J Clin Nutr 71: 1062-1076. [Crossref]

64. Mackness B, Quarck R, Verreth W, Mackness M, Holvoet P (2006) Human paraoxonase-1 overexpression inhibits atherosclerosis in a mouse model of metabolic syndrome. Arterioscler Thromb Vasc Biol 26: 1545-1550. [Crossref]

Copyright: (C2016 Jakubowski H. This is an open-access article distributed under the terms of the Creative Commons Attribution License, which permits unrestricted use, distribution, and reproduction in any medium, provided the original author and source are credited. 